\title{
Iran and Future European Union Gas Supply: Sociolinguistic Element of Iranian Gas Export Media Debate
}

\author{
Rajdeep Singh \\ Correspondence: Rajdeep Singh, University of Tehran, European Studies Department, Tehran, Iran. \\ Received: August 10, $2019 \quad$ Accepted: August 22, $2019 \quad$ Online Published: August 30, 2019 \\ doi:10.5430/elr.v8n3p1 \\ URL: https://doi.org/10.5430/elr.v8n3p1
}

\begin{abstract}
While Iran possesses one of the biggest gas reserves in the world, Iranian media debate about gas export has been concentrated around the gas pipe line strategy. On the other hand, Iran is not even yet a gas export country despite having such big gas reserves and this begs the question as to why Iran has not been successful in providing European Union with gas. Our research deals with this question and explains the future prospect of Iran-European Union cooperation in energy sector. Our main hypothesis in this research is then formulated as follows: Iranian media has been mostly captured by pro-pipe line officials who see great fortune in the possible economic benefits for them in this. However, for petroleum products, as long as Iran enjoys good relationship with Europe, it can play an important role in the oil sector. In fact, we will show that the linguistic aspect is vital as it help depict a different picture for the general public, bringing about different expectation among the youth and nationalists. Finally, we also discuss the LNG gas export possibility and the economic reasoning behind its future exploitation in Iran.
\end{abstract}

Keywords: linguistics, socio-linguistics, economics, gas pipelines, Iran, media

\section{Introduction}

Iran with its huge oil and gas reserves should have an important place in the EU's energy policy. However, despite the common sense of having Iran onboard for future European energy projects, we see an almost absence of any clear cut guidelines as to how to use the Iranian strategic position and get the EU wean off the Russian energetic dominance. In this article we will develop ideas as to why EU does not consider Iran in its current energetic projects and then we will suggest ways that EU can engage Iran in the positive direction and get its energetic demands satisfied. The European Commission sees natural gas play a critical role in the energy transition to 2035, but beyond that its views on the role of gas are much less clear. Many experts though do not believe that renewable can be ramped up and added up that quickly to replace coal generation. In fact, replacing coal has been one of the most important engagements EU took in the Paris agreement and the commission despite the critics is working on its way to finally make the EU a coal-free zone. We have on the other hand the oil which is way harder to replace by renewable, so it seems the question of replacing all of the carbonic sources to zero a demand too much to satisfy.

It does make sense then to have the question of where gas stands in the EU policy as an important one. After all, gas is not polluting and it can help the EU to shrink its carbon footprint fast. So really what role for natural gas in the low-carbon energy system of the future?

The EU's 2050 energy strategy sets herself the goal to reduce greenhouse gas emissions by something between $80 \%$ and 95\% when compared to 1990. It was considered so ambitious at its proposed time. In its Energy Roadmap 2050, published in 2012, the European Commission says it takes into consideration that natural gas is a key factor in achieving this reduction, if not in the long term, at least in the medium term. "Gas will be critical for the transformation of the energy system," it says. "Substitution of coal (and oil) with gas in the short to medium term could help to reduce emissions with existing technologies until at least 2030 or 2035.” (Energy Roadmap 2050, p.12)

Few market watchers would argue with that. But how the EU wants to deal with the period between the above mentioned dates? This is of paramount importance for the European energy industry, which in the end has to investment big money and make important decision as to the way of substituting the good old polluting resources with clean renewable. These industries have to build up that connecting bridge between what the EU wants and what are the demands of market, in a highly competitive world. So far, the industry has sold itself to the public as "the bridge" to a low-carbon energy system, but it is not that much clear how the other side of the bridge will look like. 
For the time being, the gas industry boasts itself with many supports it gets from different spectrums of the society. In a way, it enjoys a high positive image in the public. If we really want to see why Gas is considered clean compared to other fossil fuels, we just need to point out the fact that natural gas combustion emits up to $60 \%$ less carbon dioxide than coal and it's huge! If we go all the way up to see the bigger picture, then the EU will be able to use the natural gas to present herself as the good pupil, complying with her commitments. Thus, gas advocates keep thrusting for a wholesale, even if be abrupt, move from coal to gas-based electricity generation, being that quick fix the EU so desperately is searching for. They sat that Gas-for-coal substitution offers an immediate reductions on a large scale and they argument that things can be easier as the capacity in combined-cycle gas turbines already is available, having been built a few years ago and went unused since. It goes without saying that a substantial amount of the greenhouse gas reduction seen so far in the energy sector has been directly related to the gas-for-coal substitution. In the US election campaigns many pro-environment democrats were pointing out that if cheap gas replaced coal in power generation it would have contributed to a substantial decline in $\mathrm{CO} 2$ emissions.

The gas sector represents around $20 \%$ of global energy-related emissions and is one of the fastest-growing fossil fuels globally. (Energy Roadmap 2050) In Europe, we will see later on that the trend was not that positive when it comes to the gas share in the energy basket but things have been picking back up again. These all show that natural gas will play an important role in the EU's future compliance with its commitments.

\section{EU energy market}

With the exception of peat and coke, the EU is a net importer of other types of energy resources. Crude oil being the dominant energy import product is hard to be substituted anytime soon despite the strong efforts pushed by European politicians. In fact, the problem with all the fossil fuels is not just an environmental argument. The political risk of being dependent on others for energy needs is a crucial one. Under the realist framework, the commission is pushing for a more independent EU and therefore the whole energy import is seen as negative in the high ranks of EU. Crude oil largely dominates the EU imports in energy products with a share of $70 \%$ in the first semester of 2018, and then we had natural gas in gaseous state with a share of $20 \%$. When it comes to coal the condition is not as bad as other energy imports as EU has some resources to satisfy a good part of its needs domestically. Despite this, EU still needs to import the domestically unsatisfied part from abroad which fell one percentage point compared to 2017 . At the same time the share of crude oil rose one percentage point.

If we go through the monthly based average for energy valuation in the EU, we see that the monthly average value of energy products on the whole we see a mixed picture as the EU has seen a reduction in the monthly average price from 2012 to 2016 and then it sees an increase by $30 \%$ between 2016 and 2017 and by $15 \%$ between 2017 and 2018 . The reason is clear, the mentioned changes are mostly due to the rise in prices on world markets since the imports in net mass was relatively stable, experiencing only a slight increase of $5 \%$ between 2016 and 2017 and we had even a decrease of import by volume by $2 \%$ between 2017 and 2018. Figure1 illustrates the trend of EU imports of energy products. The latest figures show the downward trend of the energy bill from 2012 to 2016 reversing in 2017 and 2018 (Figure 1). The average monthly value of imports in energy products rose by $49 \%$ from $€ 17.4$ billion per month in 2016 to $€ 26.1$ billion per month in 2018. Nonetheless the energy bill is still $31 \%$ lower than its peak of $€ 38.0$ billion per month in 2012. We see that the development of the volume of energy products had much less fluctuation, remaining between 74 and 81 million tones throughout 2012 to 2018. (Eurostat, 2019) 


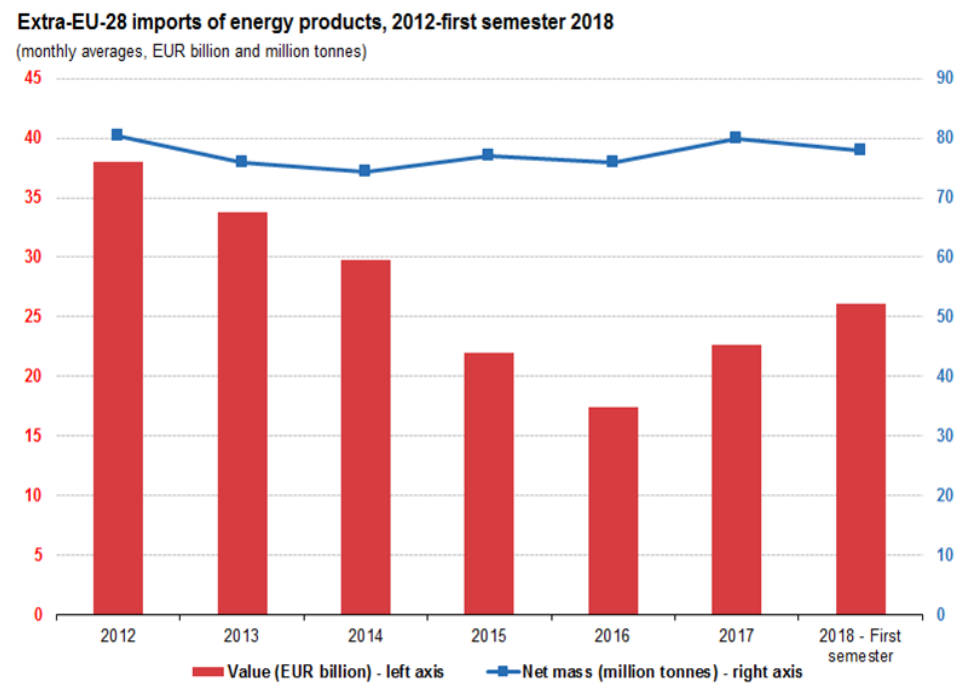

Source: Eurostat database (Comext) and Eurostat estimates

eurostato

Figure 1. EU import of energy products from 2012 up to first semester of 2018

Main suppliers of natural gas and petroleum oils to the EU

Figure 2 show how the crude oil is by far the clear import champion of EU energy market which represents $70.2 \%$ of total EU energy imports in the first half of 2018 much ahead of natural gas in gaseous state representing $20.1 \%$. If we go historically then for crude oil this was 1.3 percentage points more than in 2017 . We see a reduction in the share of coal by 1.1 percentage points. (Eurostat, 2019)

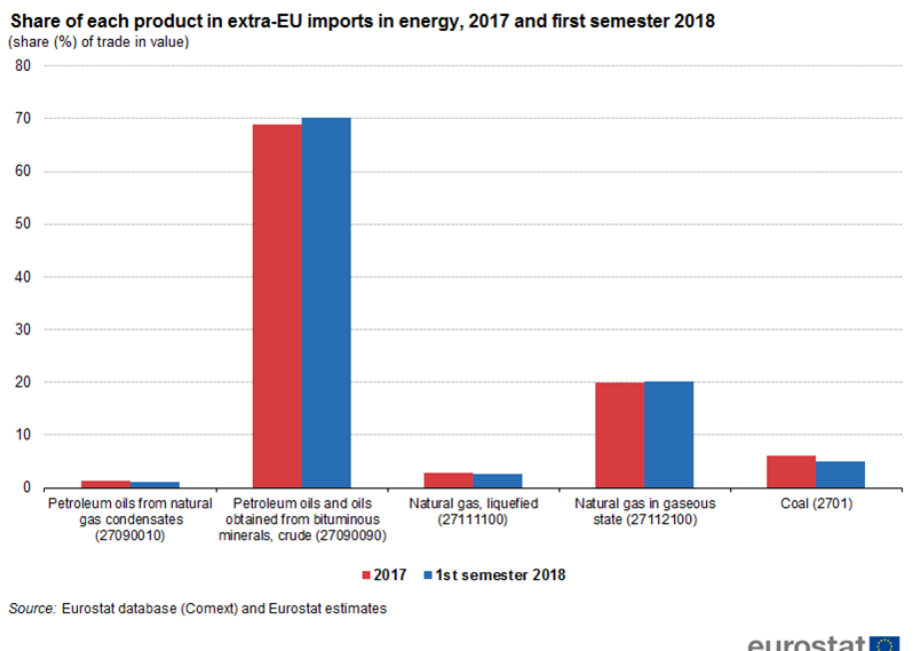

Figure 2. Energy import products by their respective share

If we look at the main suppliers, then we see Russia as the dominant player in the market. In fact, Russia singles out as the most important game changer in the EU energy system. Even though it seems really positive for Russia in many aspects, it makes Russia also vulnerable to EU energy policies, especially when it comes to gas since Russia has access to the EU market through her pipelines only and she has not developed LNG, liquidities natural gas. Figure 3 illustrates again that Russia was very active in the gas sector, being the largest supplier of natural gas to the EU, both in 2017 and 2018, and it shows that others were not truly a competitor to Russia, having much lower shares. Those partners with a significant share in total extra-EU imports were Norway and, at some distance Algeria and Qatar. If we consider the global share of all the other countries exporting natural gas to the EU was $6.7 \%$ in 2017 and $5.0 \%$ in 2018 in terms of trade value. (Eurostat, 2019) 
Extra-EU imports of natural gas from main trading partners, 2017 and first semester 2018

(share (\%) of trade in value)
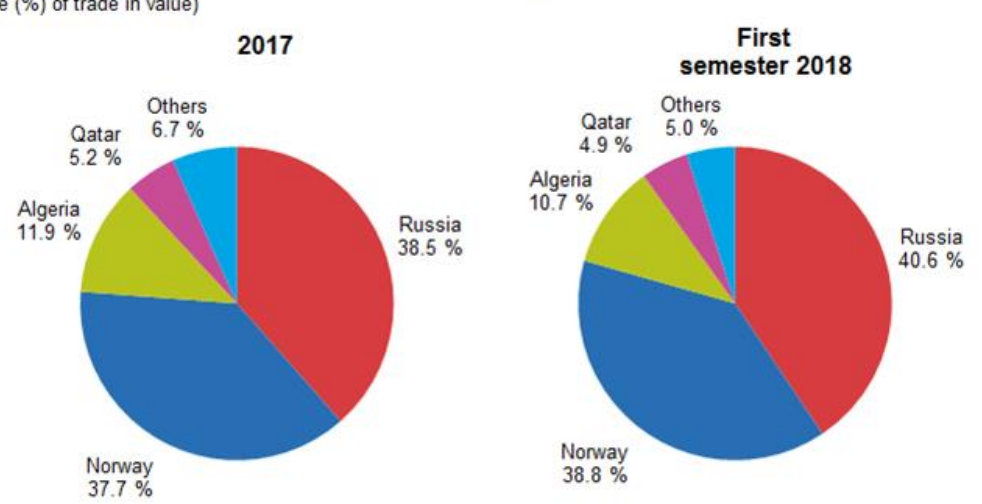

Source: Eurostat database (Comext) and Eurostat estimates

\section{eurostato}

Figure 3. Natural gas exporters to the EU

What about oil? Well here again Russia is not that dominant as she was in the gas sector. Figure 4 shows that Russia was less dominant in petroleum oils than in natural gas. Despite this she still stands far ahead of the second largest supplier, Norway. Kazakhstan and Iraq was third while Iraq replaced Nigeria as fourth largest supplier. The share of the top six dropped from $69.2 \%$ in 2016 to $67.9 \%$ in 2017. (Eurostat, 2019)

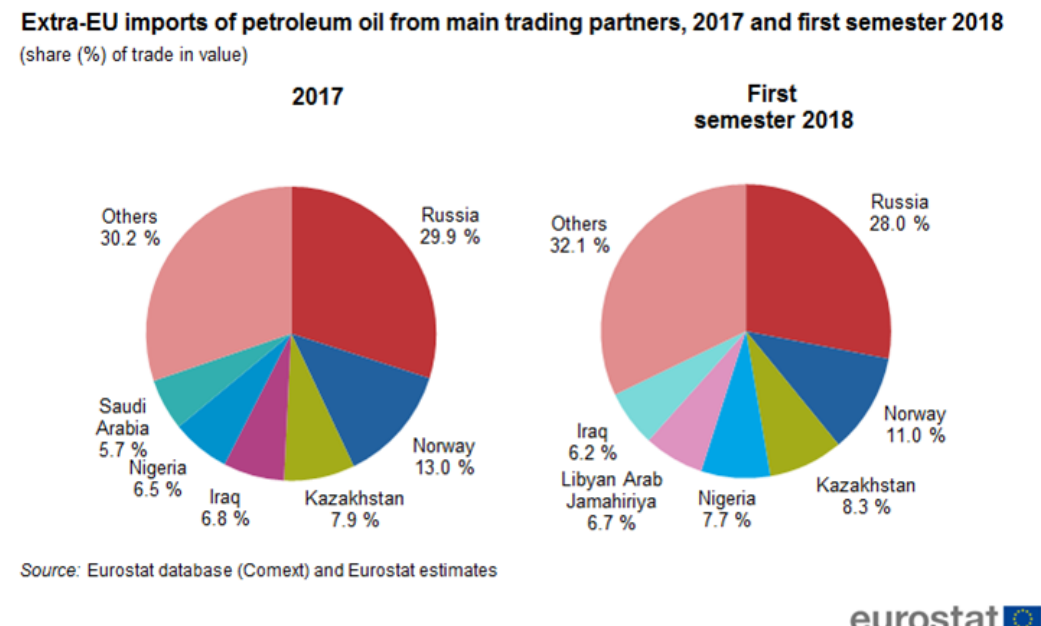

Figure 4. EU import of petroleum oil

This shows that Russia can influence the EU political sphere with her aggressive energy export to the EU. One may wonder why EU does not try to find a way out of the energy deadlock. The reason is that EU also sees Russia dependent on her EU export and this way EU may play in the Russian field, though this idea has less support than before as the Russian government and elites are highly restrictive to the EU ideas and actors, making the playing field purposely uneven for the EU players. Figure5 shows the EU imports of natural gas from Russia and the rest of the world, expressed in value and net mass. In value the extra-EU total fell between 2012 and 2016 but increased in 2017. If we were to measure it in net mass, the decline started a year earlier and ended two years earlier, following almost a U-shape with the lowest point in 2014. Therefore, we see a clear decline in value while the net mass increased from 2014 to 2015 and from 2015 to 2016 . Russian imports over the same period go on with some variations from year to year, increasing in 2017 compared to 2016. 


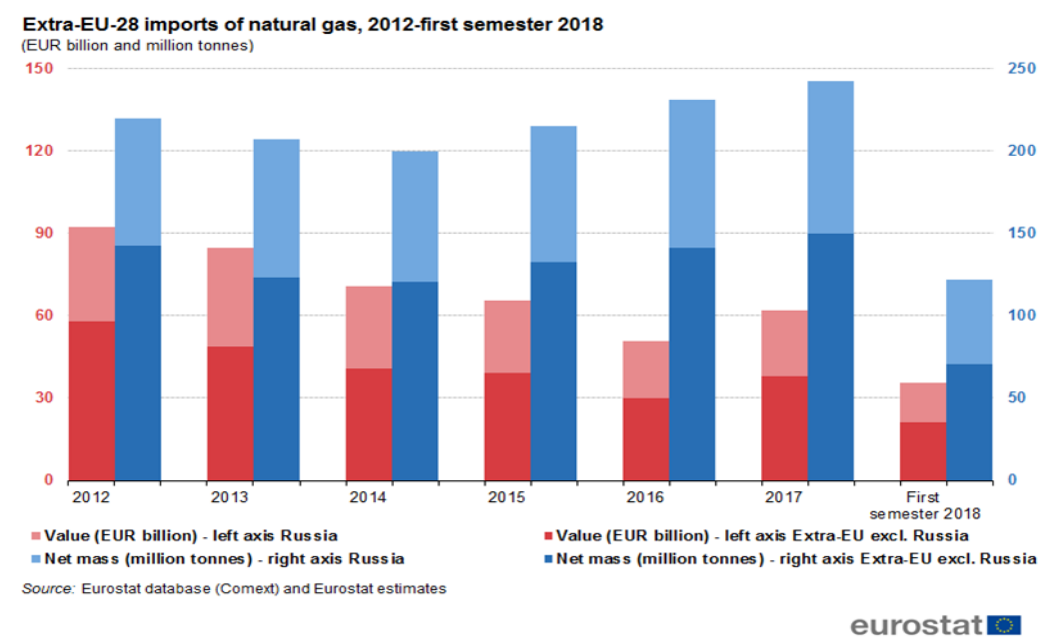

Figure 5. Russian place in EU import of natural gas

We can see the same trend of prices and volume in the petroleum oils as well. Figure6 shows that for petroleum oils the trend of total extra-EU imports in value is largely similar to the trend observed for natural gas. However in net mass the road is bumpier as there are more ups and downs although never far from 500 million tons while in value the changes are clearer. Total 2017 imports in net mass went well above the previous high of 2012. In value the share of Russia which was $33 \%$ in 2012, fell to $28 \%$ in 2015, went up to $30 \%$ in 2017 and was back to $28 \%$ in 2018 .

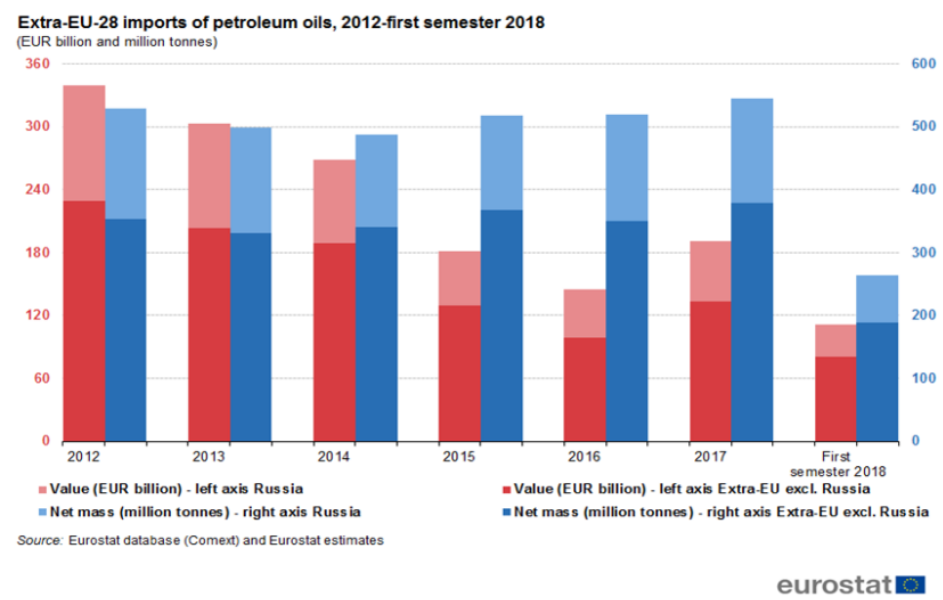

Figure 6. Russian place in EU import of petroleum oils

We can also consider the trend of energy basket in the EU energy import products. Figure7 illustrates the share in total EU imports of the main energy products considered in this article. This share stood close to $25 \%$ in 2012. It went down to $12 \%$ in 2016 before rising again to $16 \%$ in 2018. Petroleum oils represent the lion's share of imports of energy products where their share is three times higher than natural gas and ten times as much as for solid fuels in 2018. Considering only the EU imports from Russia, the share of the key energy products stood at $5.1 \%$ in 2018 which represented 0.4 percentage points higher than the $4.7 \%$ in 2017, but stood much lower compared to 2012 and 2013. In fact, it is 3.6 percentage points lower than it was in 2012 and 2013 when we had a peak of $8.3 \%$. Figure 8 illustrates the mentioned points about the historical trend of energy import from Russia. (Eurostat, 2019) 


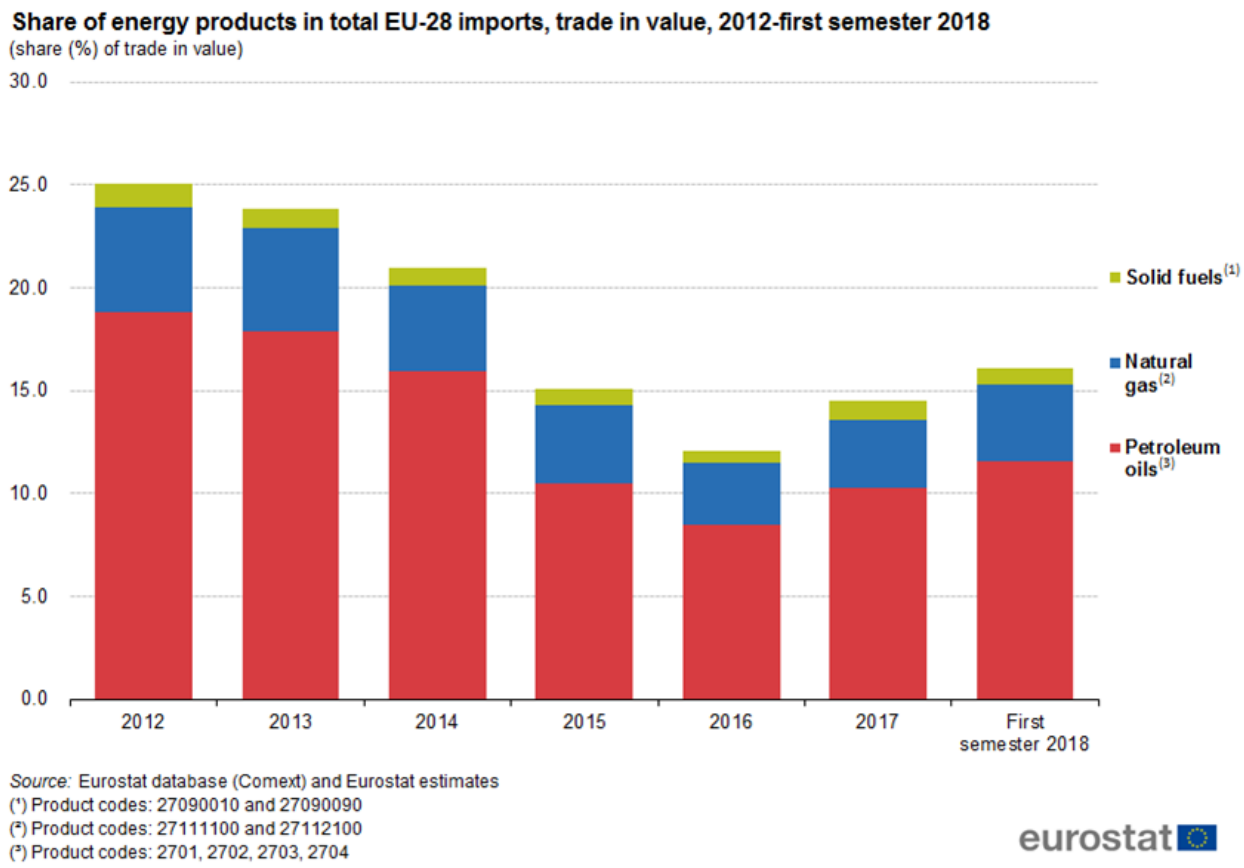

Figure 7. Share of the EU import of energy products

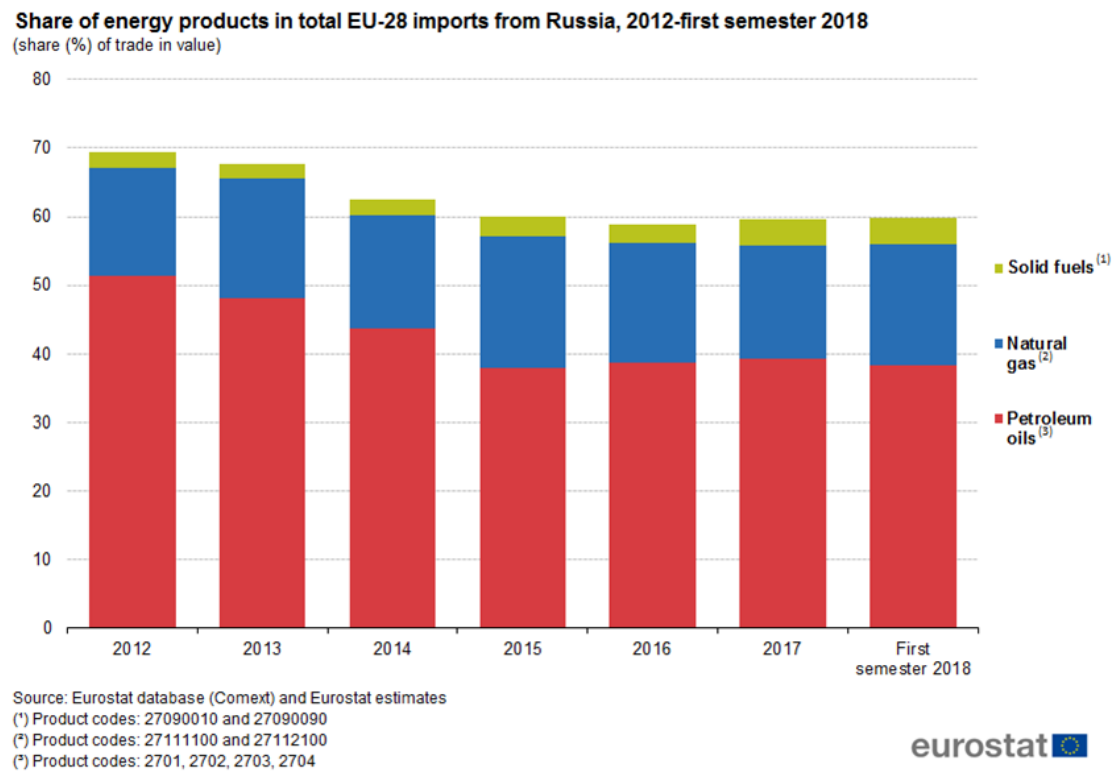

Figure 8. Share of the EU import of energy products from Russia

We have to clarify though that there is two types of energy exchange in the EU: the intra-imports and exports which are the amount of import and export happening inside the EU members, and extra-EU imports and exports which are amount of import and export between the EU members and the rest of the world. There are some countries that play an important role as the intermediary and transit country for energy products. The reason such system of double market was created was that the EU wanted to take advantage of the fact that some EU members were much ahead of others in having at their disposal the necessary refinery and converting sites for energy products. Furthermore, the EU can better negotiate her energy deals with foreign companies by having such complex but open system of supply. Table 1 shows the share of each Member State in extra-EU imports of petroleum oils and natural gas. However, we did not include the redistribution of imports among the Member States after import into the EU, as measured by intra-EU trade. As it is shown three Member States, Germany, the Netherlands and Poland have shares of more than $5 \%$ in total EU imports for both petroleum oils and natural gas. Two of those, Germany and the Netherlands have at their disposal shares of 
more than $5 \%$ in total imports from Russia for both products, which is also the case for Spain, Italy and the United Kingdom. When it comes to import of petroleum oils and natural gas in 2018, for four Member States, namely Bulgaria, Estonia, Slovakia and Finland, more than $75 \%$ of their imports in petroleum oils came from Russia which is shown in table2. For Eleven Member States, namely Bulgaria, Czech republic, Estonia, Latvia, Hungary, Austria, Poland, Romania, Slovenia, Slovakia and Finland we have their import stood at more than $75 \%$ of total national imports of natural gas from Russia. In both cases this happens for countries that are in neighborhood and close proximity to Russia. We see a different trend in countries that are further away from the Russian borders whose shares stand below $25 \%$ of imports from Russia in either product and we also have the exception of Latvia for petroleum oils. (Eurostat, 2019)

Table 1. Share of intra-EU imports and exports of natural gas and petroleum oils

\begin{tabular}{|c|c|c|c|c|}
\hline \multirow[b]{2}{*}{ Country } & \multicolumn{2}{|c|}{ Share $(\%)$ in total intra-EU-28 imports } & \multicolumn{2}{|c|}{ Share $(\%)$ in total intra-EU-28 exports } \\
\hline & Petroleum oils & Natural gas & Petroleum oils & Natural gas \\
\hline Belgium & $>20$ & $10-20$ & $0-5$ & $>20$ \\
\hline Bulgaria & $0-5$ & 0.5 & $0-5$ & $0-5$ \\
\hline Czechia & $0-5$ & $0-5$ & $0-5$ & $0-5$ \\
\hline Denmark & 0.5 & $0-5$ & $0-5$ & 0.5 \\
\hline Germany & $>20$ & $>20$ & $0-5$ & $>20$ \\
\hline Estonia & 0.5 & 0.5 & 0.5 & 0.5 \\
\hline Ireland & 0.5 & $0-5$ & $0-5$ & 0.5 \\
\hline Greece & $0-5$ & $0-5$ & 0.5 & 0.5 \\
\hline Spain & 0.5 & $0-5$ & $0-5$ & 0.5 \\
\hline France & 0.5 & $>20$ & $0-5$ & 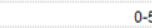 \\
\hline Croatia & 0.5 & $0-5$ & 0.5 & 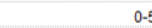 \\
\hline Italy & 0.5 & $0-5$ & 0.5 & 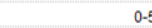 \\
\hline Cyprus & 0.5 & 0.5 & $0-5$ & $0-5$ \\
\hline Latvia & 0.5 & 0.5 & $0-5$ & 0.5 \\
\hline Lithuania & 0.5 & 0.5 & 0.5 & 0.5 \\
\hline Luxembourg & 0.5 & 0.5 & 0.5 & $0-5$ \\
\hline Hungary & 0.5 & $0-5$ & 0.5 & $0-5$ \\
\hline Malta & 0.5 & 0.5 & 0.5 & 0.5 \\
\hline Netherlands & $>20$ & $5-10$ & $>20$ & $>20$ \\
\hline Austria & 0.5 & 0.5 & 0.5 & 0.5 \\
\hline Poland & 0.5 & $0-5$ & $0-5$ & 0.5 \\
\hline Portugal & 0.5 & 0.5 & 0.5 & 0.5 \\
\hline Romania & 0.5 & 0.5 & 0.5 & 0.5 \\
\hline Slovenia & 0.5 & 0.5 & 0.5 & 0.5 \\
\hline Slovakia & 0.5 & $5-10$ & $0-5$ & $5-10$ \\
\hline Finland & $0-5$ & $0-5$ & $0-5$ & $0-5$ \\
\hline Sweden & 0.5 & 0.5 & 0.5 & 0.5 \\
\hline United Kingdom & 0.5 & $5-10$ & $>20$ & $5-10$ \\
\hline EU-28 & 100 & 100 & 100 & 100 \\
\hline
\end{tabular}


Table 2. Share of Russia in extra-EU imports and exports of natural gas and petroleum oils

\begin{tabular}{|c|c|c|}
\hline \multirow[b]{2}{*}{ Country } & \multicolumn{2}{|c|}{ Share (\%) of Russia in national extra-EU-28 imports } \\
\hline & Petroleum oils & Natural gas \\
\hline Belgium & $25-50$ & $0-25$ \\
\hline Bulgaria & $75-100$ & $75-100$ \\
\hline Czechia & $50-75$ & $75-100$ \\
\hline Denmark & $0-25$ & $0-25$ \\
\hline Germany & $25-50$ & $50-75$ \\
\hline Estonia & $75-100$ & $75-100$ \\
\hline Ireland & $0-25$ & $0-25$ \\
\hline Greece & $0-25$ & $50-75$ \\
\hline Spain & $0-25$ & $0-25$ \\
\hline France & $0-25$ & $0-25$ \\
\hline Croatia & $25-50$ & $0-25$ \\
\hline Italy & $0-25$ & $25-50$ \\
\hline Cyprus & $0-25$ & $0-25$ \\
\hline Latvia & $0-25$ & $75-100$ \\
\hline Lithuania & $50-75$ & $50-75$ \\
\hline Luxembourg & $0-25$ & $0-25$ \\
\hline Hungary & $50-75$ & $75-100$ \\
\hline Malta & $0-25$ & $0-25$ \\
\hline Netherlands & $25-50$ & $25-50$ \\
\hline Austria & $0-25$ & $75-100$ \\
\hline Poland & $50-75$ & $75-100$ \\
\hline Portugal & $0-25$ & $0-25$ \\
\hline Romania & $25-50$ & $75-100$ \\
\hline Slovenia & $0-25$ & $75-100$ \\
\hline Slovakia & $75-100$ & $75-100$ \\
\hline Finland & $75-100$ & $75-100$ \\
\hline Sweden & $25-50$ & $0-25$ \\
\hline United Kingdom & $0-25$ & $0-25$ \\
\hline
\end{tabular}

\section{RENEWABLES - EU'S AMBITIOUS TARGETS FOR 2020}

The EU and their member states have set binding, ambitious targets to promote the expansion of renewable energy sources. For example in the electricity sector, the EU expects renewable to account for $34 \%$ by 2020 . Since the implementation of the EU Directive for climate protection and energy - often referred to as the "20-20-20 package" adopted in December 2008, we see that the share of renewable in gross final energy consumption has increased in a steady way. In 2016 the share even reached $17 \%$, almost twice as high as in 2004 (8.5\%). At $53.8 \%$, Sweden's share of renewable was clearly the highest in 2016. In total, eleven of the $28 \mathrm{EU}$ member states have met their 2020 targets: Bulgaria (18.8\%, Czech Republic (14.9\%), Denmark (32.3\%), Estonia (28.8\%), Croatia (28.3\%), Italy (17.4\%), Lithuania (25.6\%), Hungary (14.2\%), Romania (25.0\%), Finland (38.7\%) and Sweden $(53.8 \%)$. Austria though misses less than 1-\%-point to reach its target for 2020. As energy from renewable will play a key role for the years after 2020 the member states have agreed on a new EU target of at least $27 \%$ by 2030 . Figure9 shows the EU members success in implementing the EU Directive for climate protection and energy so far in 2019. (Eurostat, 2019)
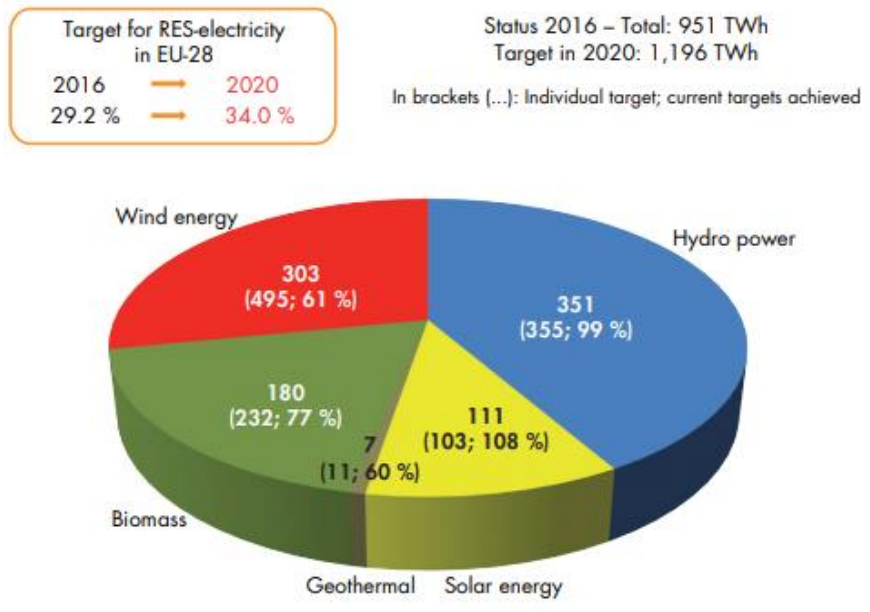

Figure 9. EU members implementation of the commission direct for renewable energy 
Nuclear power also plays an important role in the EU energy market. However, we see its share rather more likely to drop than increase. The fact is that many EU members want to become nuclear-free under the influence strong environment-lobbying groups. Even in France, which stands as the strongest EU country in the nuclear sector, and if not first the second biggest producer of nuclear-driven electricity is facing the public outcry of how harmful the nuclear energy is to the environment. So as figure10 illustrates we see a much more negative trend in the EU countries when it comes to the new nuclear power plant construction. Countries such as Germany are working hard to substitute nuclear power plants with solar and wind farms. Currently 449 nuclear power plants with a total capacity of 420,383 MW are being operated worldwide in 31 countries: another 57 plants are under construction, while roughly 200 plants are being planned or pre-planned to be commissioned by 2030 (IAEA, atw - Int. Journal for Nuclear Power, status: 6/2018). Following the Japanese events of March 11, 2011, new built plans were abandoned in Italy and Switzerland only. This does not concern the plants in e.g. East and South East Europe, Asia, states of the Middle East as well as North and South America. As said earlier, the impact of the current North American shale gas boom on local power plant structure as well as plant operation and construction of new nuclear power plants cannot be estimated yet but may further make the nuclear power plants less favorable in the EU and North America. (IAEA, atw - Int. Journal for Nuclear Power, status: 6/2018)

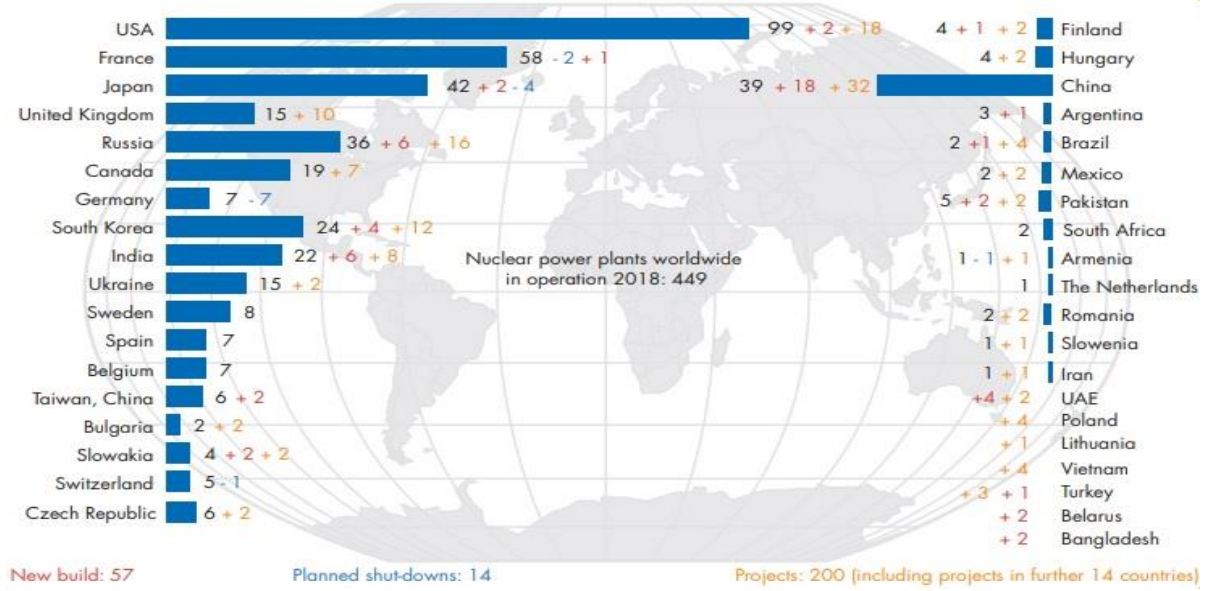

Figure 10. Nuclear power plants in the EU and the rest of the world

Many companies have begun constructing new power plants because of the enormous EU energy consumption. Despite the expansive trend in the renewable sector, the EU will remain struggling to get more coal, natural gas and nuclear energy and this is hard to change since the latter continue to be the most important primary energy sources for reliable available power generation. Highly efficient new plants are replacing less efficient power plants. Leading to a significant reduction in $\mathrm{CO} 2$ emissions, new power plants will also reduce further emissions and their increased flexibility will be a contributive factor for a secure electricity supply and the integration of renewable energy into the supply system. However, due to a lack of long term political framework conditions across Europe, investment in new capacities is stalled. The technology of gas-fired power plants accounts for the largest share of the available capacity of conventional plants at around $28 \%$ (approximately 33,348 MW). With a share of approx. $20 \%(24,270 \mathrm{MW})$ these are followed by nuclear power plant projects. This trend is particularly strong in Eastern European countries. The new construction projects for power plants fired by hard coal and lignite are in third place with a combined share of around $14 \%(16,175 \mathrm{MW})$ of the total capacity. Projects based on non-schedulable generation technologies continue to focus on wind power plants with a capacity share of approx. $28 \%(33,603 \mathrm{MW})$. (Data base VGB, state: 9/2018)

It is clear then that EU needs to diversify its supply chain of energy product imports especially as it wants to meet its long term energy policy goals. Russia plays too much a role to be ignored and EU seems to be searching for diversifying the import basket.

\section{Iran and energy sector prospect}

Iran holds some of the world's largest deposits of proved oil and natural gas reserves, ranking as the world fourth-largest and second -largest reserve holder of oil and natural gas, respectively. Iran also ranks among the world's top 10 oil producers and top 5 natural gas producers. The gas has a big share in Iran's internal energy consumption, with oil being by far the second consumption resource. Figure11 shows the energy basket of Iran. Iran is in fact now highly dependent on the gas for its energy consumption demands and internal market. 


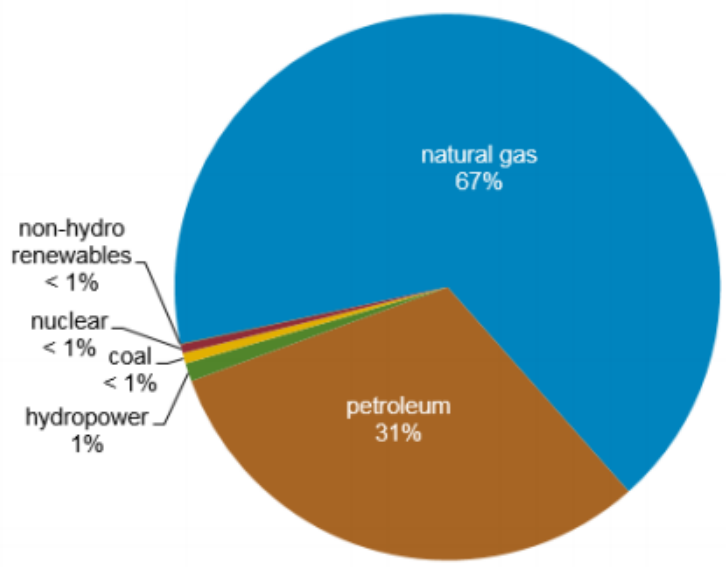

Figure 11. Energy consumption in Iran

Iran produced almost 4.7 million barrels per day (b/d) of petroleum and other liquids in 2017 and an estimated 7.2 trillion cubic feet (Tcf) of dry natural gas in 2017. 1 and consumed more than 270 million tons oil equivalent of primary energy in 2016. Iran had an estimated 157 billion barrels of proved crude oil reserves, representing almost $10 \%$ of the world's crude oil reserves and about $13 \%$ of reserves held by the Organization of the Petroleum Exporting Countries (OPEC). It produced 4.7 million b/d of petroleum and other liquids in 2017, of which 3.8 million b/d was crude oil and the remainder was condensate and hydrocarbon gas liquids. (Oil \& Gas Journal, January 2018) Iran's crude oil exports and production have declined since the May 2018 announcement by the United States that it would withdraw from the Joint Comprehensive Plan of Action (JCPOA) and reinstate sanctions against Iran. Figure12 shows the crude oil production and consumption in Iran from 2011 to 2018. Iran's oil net export revenues totaled \$55 billion in 2017. (EIA, 2018)

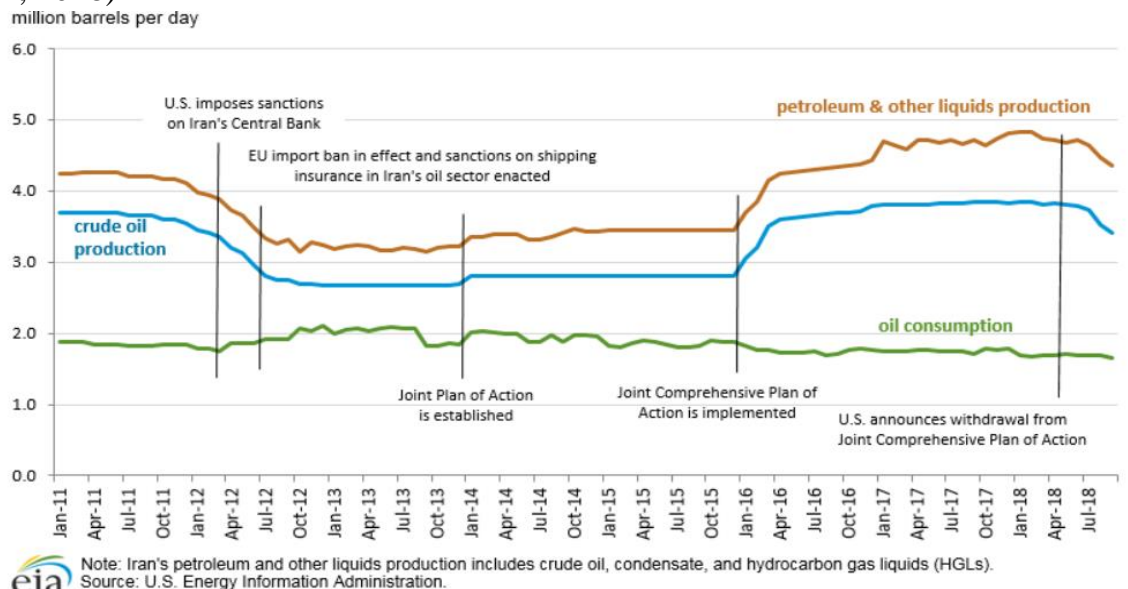

Figure 12. Historical trend of crude oil production and consumption in Iran

According to EIA estimates based on tanker-tracking data, Iran's crude oil and condensate exports averaged 2.5 million b/d in 2017, about 0.2 million b/d higher than the 2016 average(ClipperData, 2018). Figure13 shows the Iranian export monthly average. When it comes to the biggest Iranian energy import destination, China and India accounted for about $43 \%$ of all Iranian exports in 2017, and Turkey and South Korea took substantial volumes during the year Figure14 shows the biggest importers of energy products. The United States has not imported crude oil and condensate from Iran in several decades. Iran's exports of petroleum products averaged 507,000 b/d in 2017, with LPG and fuel oil accounting for about $83 \%$ of total petroleum product exports. Iran's petroleum product exports declined in 2017 compared with exports of 587,000 b/d (including small volumes of gasoline exports) in 2016. Iran's exports of crude oil and condensate peaked in June 2018 at about 2.7 million barrels per day (b/d), almost 300,000 b/d higher than the average during the first four months of the year (before the May announcement of sanctions). In September, Iran's crude oil and condensate exports has fallen to1.9 million b/d. (ClipperData, 2018) 


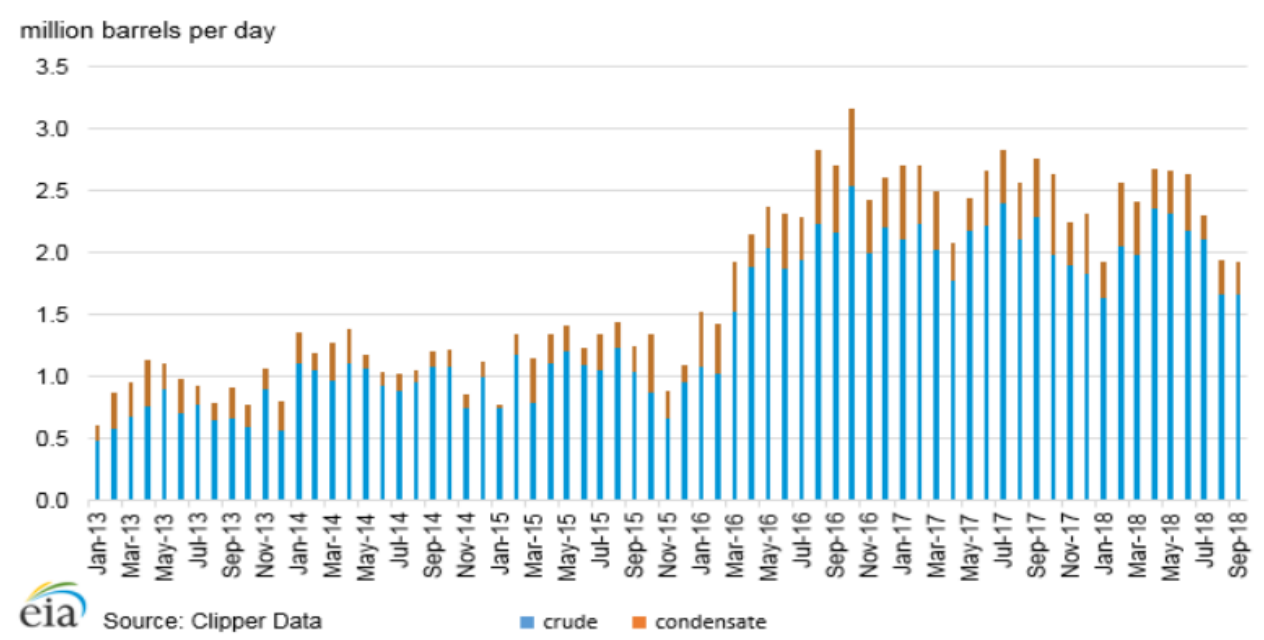

Figure 13. Crude and condensate monthly average production

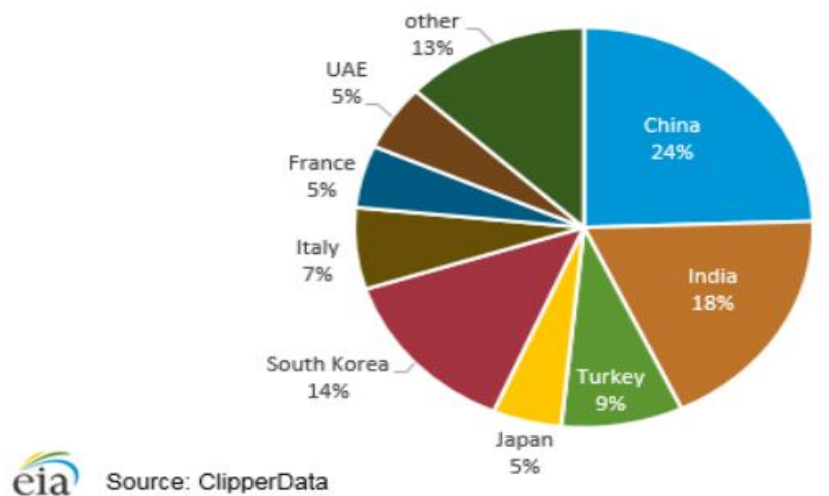

Figure 14. Biggest export destination for Iranian energy products

Iran is the world's third-largest dry natural gas producer after the United States and Russia. Iran's gross natural gas production totaled nearly 9.5 Tcf in 2017 , of which 7.3 Tcf was dry natural gas, rising almost $9 \%$ compared with 2016. (Rystad Energy, 2018) Roughly 1.6 Tcf of the total was reinjected into oil wells for enhanced oil recovery (EOR) which plays a central role in Iran's oil production. In addition to the natural gas used for EOR, Iran vented and/or flared approximately $0.6 \mathrm{Tcf}$ of gas in 2017. Figure15 illustrates the way Iran has been using its gas in the oil industry as well. In fact, Most of the natural gas produced is consumed domestically, with Iran's consumption averaging at an estimated $6.9 \mathrm{Tcf}$ in 2017.

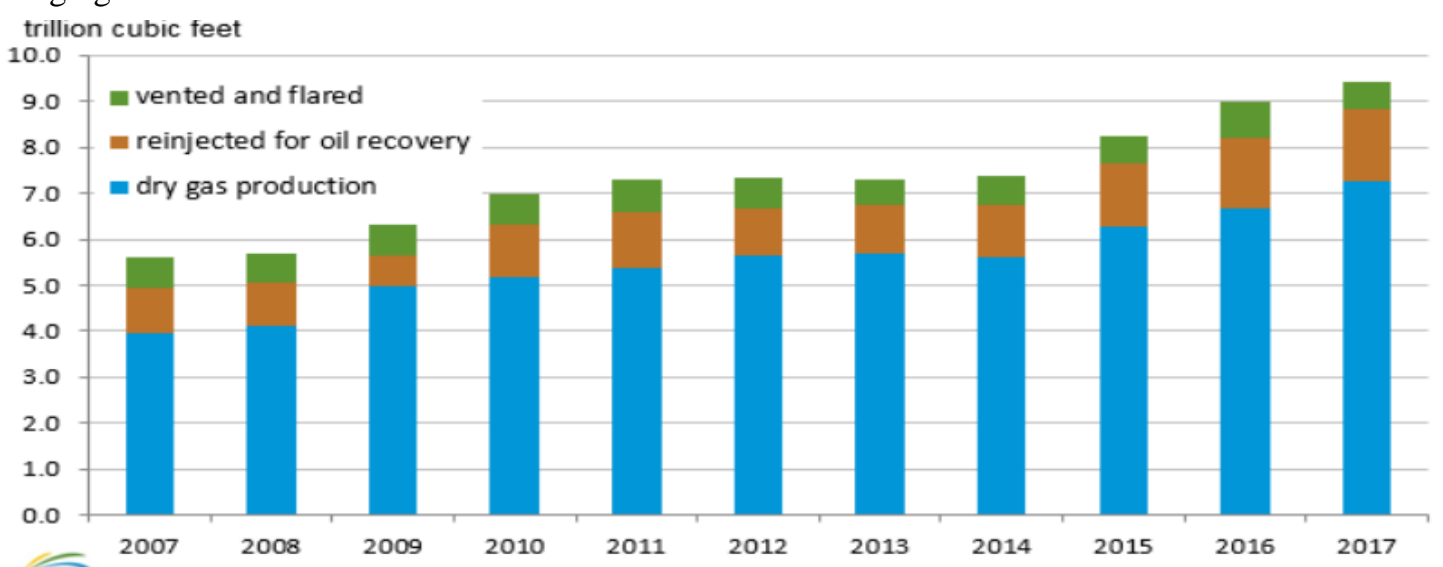

eia Source: Rystad Energy

Figure 15. Natural gas production in Iran 
Iran exports natural gas via pipeline to Turkey, Armenia, Azerbaijan, and Iraq, and it receives imports from Turkmenistan. In 2017, Iran exported about $450 \mathrm{Bcf}$ and imported 170 billion cubic feet (Bcf) of natural gas via pipelines which has been shown in figure16. In 2017, about $73 \%$ of total natural gas exports were destined for Turkey. Natural gas exports to Armenia averaged $36 \mathrm{MMcf} / \mathrm{d}$ in 2017, in return for which Iran received electric power. Iran and Armenia trade natural gas and electric power via a 20-year swap contract.

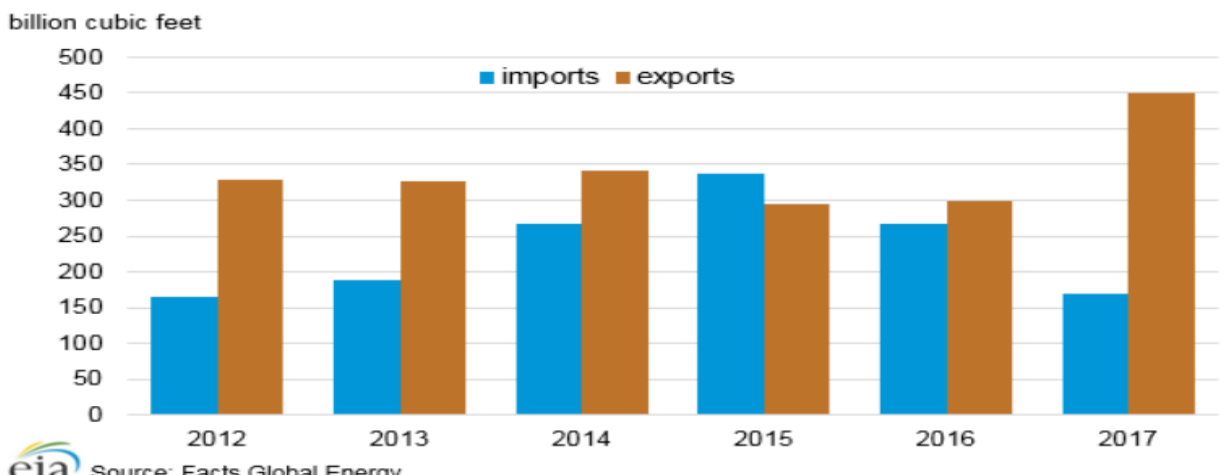

Figure 16. Iran's natural gas pipeline export and import

\section{Iran and European energy sector needs}

The EU is one of the world's largest consumers and importers of energy resources. Its domestic production is declining, and EU member states are becoming more dependent on countries outside the EU or from the non-EU countries in the European Economic Area (such as Norway). As we mentioned earlier, about 53 percent of overall energy consumed by EU countries depends on imports: about 90 percent of their petroleum is imported, and 66 percent of their natural gas.In the last 20 years in fact overall gas production in the EU has fallen by 56 percent, and now the member states import almost $300 \mathrm{bcm}$ of natural gas each year. In the next decade, it will rise to $340-350$ $\mathrm{bcm} / \mathrm{y}$.

As we pointed out earlier, Russia is the main energy supplier to the EU, with an oil and gas market share of about 30 percent. Yet disagreements about the fragmented nature of the market and uncertainties surrounding the reliability of Russia as a gas supplier have forced the European Commission to pursue a broad strategy to reduce European dependency, especially in the central and eastern member states. The bulk of this trade involves pipelines, and prices are determined by long-term contracts between Gazprom (or some non-Russian supplier) and the wholesale buyer in the consuming nation. These sorts of long-term contracts include a "take or pay" clause that obliges importers to buy an agreed-upon volume of gas or else pay a fine. Gas prices are linked to oil prices with a time lag of about six months. Though Russia argues that this arrangement secures the gas supply for a period of 20-30 years, according to a growing body of opinion in the EU, actively promoted by the European Commission, Gazprom can effectively manipulate the gas market at the expense of consumers, who have to pay a punitive contract price. (Yafimava, 2013)

Moreover, price disputes between the Russian Federation and Ukraine in 2006 and 2009, which resulted in the disruption of gas supplies to Europe, undermined Russia's reputation of a reliable supplier. 2014-15 military conflict in Ukraine once again raised questions about the security of supplies. These issues are reflected in the 2014 European Energy Security Strategy, which states that "[t]he most pressing energy security-of-supply issue is the strong dependence [on] a single supplier."Therefore, "the European Union must reduce its external dependency on particular suppliers."(European Energy Security Strategy Russia, 2014) though not mentioned, is clearly assumed to be the referent. (Aad Correljé, Martijn Groenleer \& Veldman Jasper, 2013)

As for remedies for this "external dependency," the European Commission proposes three strategic measures, already included in the EU's primary law: first, it encourages energy efficiency and greater use of alternative fuels; second, it actively pushes for diversification; and third, it promotes the creation of an internal gas market with a larger role for the EC in its regulation. The last point assumes a shift from a market based on long-term contracts to a spot market regulated by the commission.

\section{Third Energy Package}

Though there has been some progress on renewables in the energy mix of some member states, it is clearly not adequate to limit import dependency. Nevertheless, significant progress was attained in the middle of 2009, when the 
EU finally adopted the so-called "Third Energy Package." (The Completion of the EU Internal Energy Market 'Getting to 2014, 2011) It was, according to then-Commissioner for Energy Günther Oettinger, a crucial prerequisite for the creation of the internal gas market. The package presumes an increase in competitiveness through a dismantling of vertically integrated companies such as Gazprom (those that control upstream, downstream and transportation). The mechanism is called "unbundling." Under this provision an independent operator will provide, to a non-discriminatory third party, access to the transmission infrastructure.

The rationale for this measure: if there are more traders on the market with access to the pipeline, the market will have higher liquidity, and competition will drive prices down. This logic led to the adoption of the non-binding but politically important Gas Target Model, which envisions a complete shift from a market regulated by long-term contracts - preferred by Gazprom - towards a spot market, where buyers can freely choose the source of gas. This will effectively deprive Gazprom of its ability to dictate contract terms and give the EC an instrument with which to regulate the market. (Gazprom, 2015)

\section{LNG and Europe}

The enthusiasm for the active promotion of the spot market was a temporary gas glut that appeared just as the Third Energy Package was enacted. This other supply was a result of the so-called shale-gas revolution in the United States; LNG (primarily from Qatar) that was originally destined for the American market was poured into the EU at almost fire-sale prices. Furthermore, after the world economic crisis in 2008, overall consumption in the EU declined. The effect of these events was that spot-market prices fell, while Gazprom's oil-linked long-term contract prices remained high; consequently, its market share declined from 28 percent in 2008 to 23 percent in 2010. The low spot-market prices helped the EC to convince the energy-intensive industries and reluctant governments to support the transition to the spot market.

Thereafter, however, the situation stabilized. Due to higher demand for LNG in Asia, LNG supplies to the EU steadily declined, the gap between spot prices and Gazprom's long-term contract prices closed somewhat, and Gazprom recovered its market share.To continue the process of market integration and liberalization, it is necessary to ensure the liquidity of the spot market. For this reason, the search for alternative suppliers would be necessary even without the recent political tensions with Russia - though the current conflict accelerated this process. As some recent reports suggest, European officials are "quietly increasing the urgency of a plan to import natural gas from Iran, as relations with Tehran thaw after JCPOA while those with top gas supplier Russia grow chillier." Thus, according to an internal document prepared for the European Parliament, Iran can be "a credible alternative to Russia." Meanwhile, we have the sanctions imposed by the US again in 2018. In fact, EU did not consider Iran as that alternative since the lift of US sanctions. We will develop the reasons why Iran could not become an alternative to Russia for the EU.

Iranian gas capacity

In spite of the fact that Iran sits on 33.8 trillion cubic meters (tcm) of natural gas (about 18.2 percent of the world reserves), it has been unable to fully develop its export potential. It exports less than 10 billion cubic meters per year (bcm/y) to Turkey, around $2 \mathrm{bcm} / \mathrm{y}$ to Armenia and only $0.5 \mathrm{bcm} / \mathrm{y}$ to Azerbaijan. (British Petroleum, 2015) This is caused by excessive domestic consumption of natural gas and the generally degraded condition of the Iranian energy industry. It is not well-balanced and is hampered by structural problems: underinvestment in the upstream sectors; poor management of the National Iranian Oil Company (NIOC); and the low energy efficiency of the economy, which is constrained by consumer subsidies.

\section{The upstream sector: Oil}

With the lifting of sanctions, Iran is planning to make a comeback on the world energy markets. Iranian Minister of Petroleum Bijan Namdar Zanganeh has already declared that NIOC plans to raise production to a pre-sanctions level (about $4 \mathrm{mb} / \mathrm{d}$ ) and to regain its lost market share. Indeed, the sanctions imposed by the EU in 2010 and 2012 hit Iran's energy industry very hard, as Iran lost access to foreign capital, technology and European energy markets. (U.S. Energy Information Administration, 2015) Between 2011 and 2013 Iran experienced an almost 20 percent fall in its crude-oil production, and its exports were halved. According to the Russian Energy Research Institute of the Russian Academy of Science after sanctions are lifted, Iran will be able to increase its oil production up to 265 million tons (about $5 \mathrm{mb} / \mathrm{d}$ ) by 2020. Subsequently, its production is bound to decline to 230 million tons $(4.6 \mathrm{mb} / \mathrm{d}$ ) by 2040 . (Vakhshouri, S. 2015)

A decline in Iran's production capacity is inevitable since most of its oil fields are at a mature stage with high rates of natural decline. To maintain production levels, Iran has to enhance its oil-recovery projects, which involve significant 
quantities of gas and water reinjections. In 2008, the volume of gas reinjections was about $26 \mathrm{bcm} / \mathrm{y}$, and was predicted to reach $64 \mathrm{bcm} / \mathrm{y}$ in 2015 . However, according to available data, since 2011 the gas reinjections have actually never reached more than 60 percent of the projected targets. (Vakhshouri, 2015)Until the imposition of the sanctions, petroleum constituted almost 80 percent of Iran's total export value; therefore, a priority should be to provide gas for reinjections rather than export.

\section{Gas}

Natural gas accounts for 61 percent of the Iranian energy mix. In just the last decade, Iran's gas production doubled; it had increased eightfold between 1989 and 2014. Yet, this was accompanied by skyrocketing consumption as the mix shifted from oil to gas. (Paul Stevens, 2015) Consequently, the rates of natural-gas production and consumption have been almost equal. Moreover, due to the unchecked consumption between 1997 and 2012, Iran became a net gas importer, buying gas from Turkmenistan. According to the Energy Information Administration, the recent drop in imports was a result of sanctions on financial transactions rather than increased domestic production or energy efficiency. Iran thus still struggles to satisfy domestic demand and is burdened by a large energy deficit. (Nader Habibi, 2014)

Nevertheless, when sanctions are lifted, Iran is expected to dramatically increase its natural-gas production. According to ERIRAS, it could make "the most significant contribution to increased global supplies of natural gas."(Makarov and Grigoriev, 2013) In the period 2010-40, under optimal conditions, Iran could increase its natural-gas production almost 2.5 times, reaching almost $370 \mathrm{bcm} / \mathrm{y}$, compared to the current $172 \mathrm{bcm} / \mathrm{y}$. This will mainly depend on the pace of the development of the giant South Pars field in the Persian Gulf. However, as Singh (2018) emphasizes there is interplay between the socio-economic perspective as well as linguistic aspect, which can be illustrated in the way contracts between Iran and Russia were signed.

\section{South Pars}

South Pars contains approximately 40 percent of the Iranian natural-gas reserves, and represents about 5 percent of global reserves. Given that the production capacity in most of the other operational fields has already peaked, successful development of South Pars is a strategic priority for the Iranian government. The whole project is divided into 24 phases with total costs exceeding $\$ 100$ billion. Development is, however, behind schedule.

Iran has completed the first 15 phases. The rest of the project will be finished only during the first half of the next decade. Obtaining assistance from international energy companies is crucial, but it has always been a problem. According to Minister of Petroleum Zanganeh, Iran "urgently" needs about $\$ 40$ billion for the South Pars project. (SHARGH, 2016) Even before the 2010 sanctions, however, when European companies were banned from investing in the country's oil and gas industry, Iran struggled to attract the necessary foreign investment.

Besides the gas shortages on the domestic market, the delays in the South Pars project led to an insufficient amount of gas for reinjections, which led in turn to a failure to meet oil production targets and Iran's OPEC quota. The lifting of economic sanctions is, however, a necessary but not sufficient condition for ensuring the access of foreign direct investment to Iran's energy sector and boosting its production. The mismanagement of the Iranian energy industry, the unfavorable investment climate and high subsidies for energy consumers are long-term problems the current Rouhani administration has to address.

\section{Mismanagement and Foreign Partners}

Contrary to public perceptions, Iran has significant political pluralism. Yet this has a negative impact on the development of a clear energy strategy. There is little delegation of power in the energy industry, leading to interference from various political actors. A common problem in many oil-producing states is that national oil companies are, on the one hand, under pressure to increase their investment in the development of energy resources and, on the other, to provide the government with finances for social programs at the expense of the company's budget. Thus, members of government who are also oil company executives find themselves in a dilemma.

The president and vice president of Iran preside over the general assembly of NIOC, which determines the company's budget and the general direction. The minister of petroleum, as chairman of NIOC's board of directors, implements its policy. NIOC's budget is then approved by the Ministry of Planning and the Majlis. Members of parliament can promote their own political agenda and are often engaged in political infighting with the incumbent administration. Moreover, as NIOC's budget has the status of law, the Guardian Council may check its consistency with Islamic law. The final outcome is thus a compromise between various political actors. 
Despite the fact that Iran needs foreign investment and technology, this politization and Iran's poor investment climate prevent the building of strong relationships with international oil companies (IOCs). In 1990, Iran made a strategic decision to open its energy sector to international investors and introduced buy-back contracts. As Paul Stevens explains, this decision reflected "its concern that the sector was falling behind" and was an attempt to break the country's isolation. Although some European companies have entered the Iranian market since then, the conditions that were offered by the Iranian government were not attractive enough for most foreign investors.

According to the Iranian constitution, only the state can own the country's natural resources, and Iranian law does not allow production-sharing agreements. Instead, Iran utilizes buy-back contracts, like service contracts whereby IOCs operate with a fixed rate of return in a payback period of between five and seven years and cannot book the reserves, which means that they cannot claim the share of hydrocarbons among their assets and thus cannot raise capital against these reserves. IOCs have to invest their own capital and expertise for the development of oil and gas, but when the production is launched, NIOC takes operatorship and repays the capital costs through the profits. In addition, the Majlis has become involved in the monitoring of the buy-back agreements, bringing domestic political considerations again into the relationships with foreign partners. Despite the fact that Iran has changed the structure of the buy-back contracts several times, this scheme has never provided enough incentives for the IOCs to massively invest in the upstream sector. Up to the imposition of EU sanctions in 2010 and 2012, only a few contracts for oil production were struck.

\section{Subsidies}

Besides the setbacks in the upstream industry, energy inefficiency caused by massive consumption subsidies, especially for gas, also limits Iran's export potential. Since gas prices have been kept much below the world level, consumption "grew significantly more than average annual GDP (4.1 percent) and at almost the same rate as production (9.5 percent)." In 2010, President Ahmadinejad tried to improve the situation and introduced a major subsidy reform. By 2015, individual consumers were supposed to pay 75 percent of the export price, and by 2020, industrial consumers were to pay 65 percent. Yet, in order to limit the impact on individual consumers, the government provided partial compensation of about $\$ 18.20$ per household, about 50 percent of the amount earned after the subsidy cuts. Moreover, "in the three years since the reform, energy prices remained fixed, declining in real terms by over 60 percent." President Rouhani is also trying to improve the situation by continuing the subsidy reforms. Prices of petrol and gas for domestic and commercial consumers have increased by 43 percent and 15 percent respectively. Despite recent progress, overall gas consumption will increase: the government plans to provide gas for three million households and 19,000 industrial units by 2018. (Habibi, 2014)

The country's power generation also depends heavily on natural gas - about 70 percent. In the last 10 years, power-generation capacity has almost doubled and further growth is projected. Yet the growth rate might not be as steep as in previous decades. Besides the subsidy cuts, the government has set itself the goal of decreasing the energy intensity of the economy 50 percent by 2021 . Today, waste reportedly accounts for about a quarter of all energy consumption in the country.

\section{Gas-Export Capacity and optimistic scenario}

As for today, the national priorities of the Iranian gas industry are ranked in the following order: firstly, domestic consumption; next, reinjection in the maturing fields, and only thirdly exporting gas.

Of course, the aforementioned discussion of strategic thinking (or the lack of it) in the energy industry suggests that these priorities are far from certain. Nonetheless, if the estimates for reinjections are correct, the volume of gas available for export will be very limited despite the considerable growth in production. In 2015, the reinjections are supposed to reach $64 \mathrm{bcm} / \mathrm{y} .{ }^{71}$ Iran also plans to finish phases 15 and 16 of South Pars in the same year. Together with phase 12, launched in 2014, they will produce about $50 \mathrm{bcm} / \mathrm{y}$ - not enough to cover the rising volume of reinjections in the same years. (Makarov and Grigoriev, 2013)

The South Pars project will be completed during the first half of the next decade, the new phases providing about 143 $\mathrm{bcm}$ of gas annually. By 2030, total gas production may rise to $250 \mathrm{bcm} / \mathrm{y}$, but reinjections might reach 90 $\mathrm{bcm} / \mathrm{y}$. Thus about $160 \mathrm{bcm} / \mathrm{y}$ are left for both domestic consumption and export (in 2013, total gas production was $164 \mathrm{bcm}$ ). This point is important; Iran was unable to reach its production and export targets even before the last round of harsh economic sanctions. (Makarov and Grigoriev, 2013)

The high domestic consumption still hinders Iran's gas exports to the EU. After 2012, when the EU declared an embargo on oil and gas imports, Iran's annual GDP growth rate collapsed, along with the country's industrial production. At the same time, its gas consumption plateaued. Hence, after economic sanctions are lifted, we can 
expect a rapid rise in domestic consumption as the economy recovers and oil production is increased. In the most optimistic scenario, the overall gas exports cannot reach $30 \mathrm{bcm} / \mathrm{y}$ until 2025 at the earliest. This shows that Iran really cannot become an alternative to Russia which exported $210 \mathrm{bcm} / \mathrm{y}$ in 2018 . The main problem that Iran somehow should overcome is this huge internal consumption of gas. In our view, the alternative of constructing costly gas pipeline for such low export capacity would be the LNG, liquidified natural gas. In fact, Russian experience and loss of market shows that production of LNG in Iran can benefit both EU and Iran. EU will become more independent of Russian gas and Iran will have a good international market for its gas. (Jonathan Saul and Henning Gloystein, 2014)

\section{Linguistic Elements of the Iranian Debate on Gas}

On a whole different plane, we need to analyze the way government tries to sell the already proven failure of gas pipe-line to population. Economically such big projects like gas pipe-lines are hard to be justified. Therefore, government is using the linguistic sensibility to raise support for its future gas pipe-line project which can bring huge economic benefit to few rent seekers and leave the majority of population suffer for the bad management. The opposite plan, LNG gas, is not supported as it needs a lot of political concession to Western companies, thus reducing rent seeking possibilities and bringing autonomy at risk. In different official media, official experts from the Iranian state oil company, regularly emphasize the importance of geopolitical power attached to gas export by pipe-line, or self-sufficiency which is khodkafaii in Persian. They further connect this notion with having the largest gas reserve and thus freedom of choice and action, azadiye amal in Persian, to convey a meaning of superiority and control of the situation. This socio-linguistic element brings a socio-linguistic dimension to the economics of gas and that is the independence of country, or esteghlal in Persian. We can summarize the process in the figure 16.

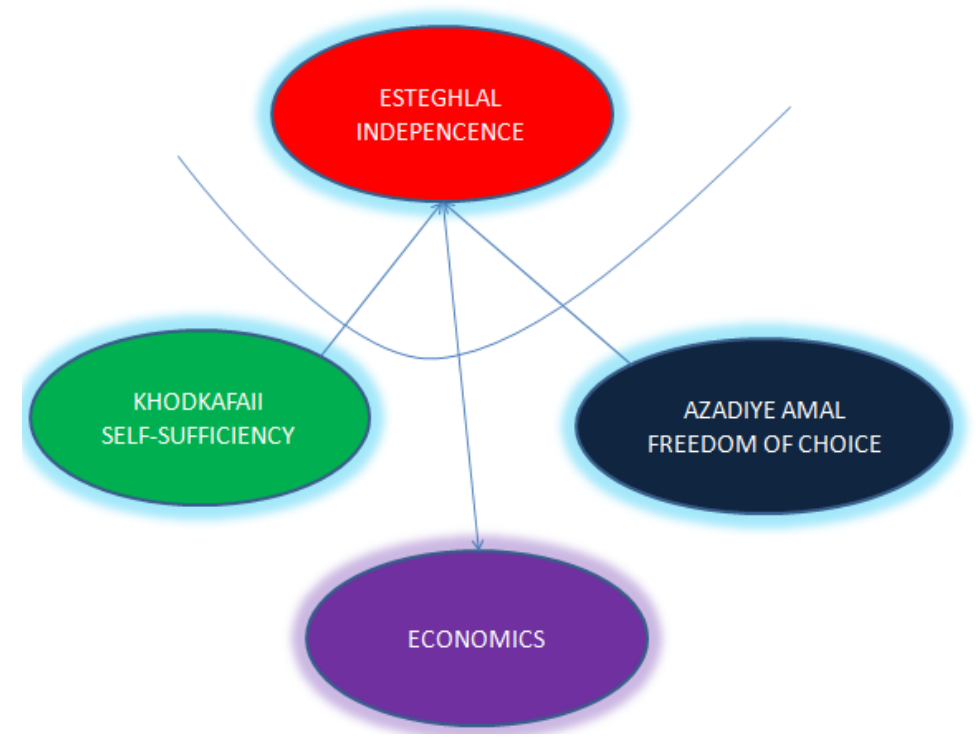

Figure 16. Linguistic element of economic preference

Thus as it is shown in the figure16, government tries to make an economic case for the gas pipeline by connecting social values such as self-sufficiency and freedom of choice and producing a national concept, the independence. In this process, it doesn't matter what economically is feasible since government succeeds in rallying people behind one national value which is independence, while selling them the economically unviable concept of gas pipe-line. As further we will see, the Russian experience doesn't suggest any clear success in the gas pipe-line implementation since should have Russia invested in LNG factory, it would have brought much more wealth for its people.

\section{Russian experience of gas pipeline and LNG}

The market of LNG has now been operating for more than 50 years. LNG first appeared in commercial circulation in the late 1950s. It is assumed, however, that the international trade in LNG started with the launch of its production in Algeria in 1964 and the commencement of deliveries to the British market.

The 1960s and 1970s marked the beginning of a dynamic expansion of the gas pipeline network from North Africa to Europe and the commencement of exploitation of the gas fields in the North Sea. Then came the rapidly developed 
gas pipelines transporting conventional natural gas from then Soviet Union to the markets of Central and Southeast Europe (CSE), and then to Western Europe.

These processes hindered the development of the European LNG market. That is why the leading role on the emerging global market of LNG was taken by Asian countries, and in particular Japan and South Korea, which are still the largest importers of this fuel today.

A new phase in the development of that market began with the launch of LNG production in Qatar in 1996. That country quickly became a leading exporter of it. In 2017, it exported 77.5 million tons of LNG (26.7 per cent of global exports). The subsequent positions among the biggest exporters were taken by Australia -55.5 million tons (19.2 per cent), Malaysia - 26.8 million tons ( 9.2 per cent), Nigeria -25.7 million tons ( 8.9 per cent), Indonesia 18.7 million tons (6.5 per cent), and the United States - 16.6 million tons (5.7 per cent). It's especially worth noting the phenomenon of Australia, which doubled its export over the last two years: from 27.6 million tons in 2015 to 41.5 million tons in 2016 and 55.5 million tons in 2017. (Carter, 2014)

According to the report entitled "LNG Trade \& Transport 2018", prepared by the British analytical center Clarksons Research, the demand for LNG accounts for 11 per cent of the global demand for gas, while back in 2000 its share was 6 per cent. However, LNG exports already account for 35 per cent of the global trade in gaseous fuels, compared with 26 per cent in 2000 .

Europe and Asia in the LNG Pursuit

In 2017, the global exports of LNG reached the level of 289.8 million tons, growing by 9.9 per cent annually, which is the highest rate of growth in years. Almost 72.9 per cent of the demand came from the Asian market, which imported 211.2 million tons (an increase of 10.2 per cent). The highest volume of LNG was imported by Japan 83.5 million tons, followed by China, which imported 39 million tons (an increase of 43.2 per cent), and South Korea (imports of 37.8 million tons). ). (World Energy Outlook 2016, IEA, 2017)

There are over 100 LNG terminals in the world. In Europe alone, there are 24 such facilities, with a capacity exceeding 150 million tons. It's worth noting their low levels of capacity utilization only approximately 25 per cent. In 2017, the LNG imports of European countries increased by about 7.5 million tons, i.e. by approximately 20 per cent. According to experts, the strong growth in demand for LNG on the European market will last for at least the next 10 years. (Khatinoglu, 2017)

On the global fuel market, LNG is strengthening its positions at the expense of conventional gas. Over the last 10 years, global LNG exports have increased by 87 per cent, while exports of gas delivered via pipelines only rose by 6 per cent. According to widespread opinions, these trends will continue in the future, and the share of LNG in the global export of gaseous fuels will exceed 40 per cent by 2023. (Carter, 2014)

The experts from the International Energy Agency (IEA) presented such predictions in a report published in June of 2018. They noted that in light of the dynamic increase in demand, an LNG supply shortage may appear on the market already in 2023. (International Energy Agency (IEA), June 2018) This is rather surprising, as in the recent years the possibility of an opposite scenario was discussed more.

\section{Russia and the future of LNG market}

According to popular assessments, LNG is the future of the gas market. In a report entitled "World Energy Outlook 2016", the International Energy Agency interprets the dynamic growth of LNG production and exports as a symptom of the second gas revolution (the first one was related to the large-scale emergence of shale gas in the years 2010-2012). (World Energy Outlook 2016, IEA, 2017) In an updated forecast published in November of 2018, the IEA predicts that LNG will account for 60 per cent of the global gas trade in 2040. Because of these processes, the gas market is becoming a global market, which could not be guaranteed by the traditional gas market, in which the exporter and the importer were inevitably dependent on each other and on connecting them pipelines, leading to the segmentation of the gas market into local markets.

For years, Russia has been passively observing the changes taking place in the global gas market. The Russian gas company Gazprom - oftentimes in denial of reality - failed to notice the genuine competition and threat posed by LNG to its traditional gas supplies. There are many analyses and studies confirming that Russia — seeing itself as a gas empire - identified the limits of its influence with the spread of Russian gas and the length of its gas pipelines: the further the reach of its pipelines the broader its influence. This thinking was at the heart of the official energy strategy pursued by Russia for many years, in particular in the part concerning foreign expansion. ). (World Energy Outlook 2016, IEA, 2017) 
During this time on the global gas marketplace, new fuel liquefaction and regasification plants were built, and producers such as Qatar, Australia and the United States were competing for the main positions on the LNG marketplace. Meanwhile, Russia has been imposing and puts into effect its high-priced infrastructure projects, which are often driven by means of its political goals and are regularly indifferent from the monetary reality. These tasks include, amongst others, Nord Stream 2, Turkish Stream, or the Power of Siberia, and before that the South Stream project, blocked by way of the European Union in 2014.

The first Russian LNG production terminal - Sakhalin 2, with a production capacity of 9.6-10.6 million tons — was launched in 2009. It would be difficult to call it a purely Russian project, however. The terminal, developed since the early 1990s, belonged to Shell (55 per cent), Mitsui ( 25 per cent), and Mitsubishi (20 per cent) until 2007. Only then, as a result of actions bearing the marks of a forced takeover, Gazprom acquired a 50 per cent stake, reducing the shares of the other participants (Shell's stake was lowered to 27.5 per cent, Mitsiu's to 12.5 per cent, and Mitsubishi's to 10 per cent).

According to analysts, continued attachment to traditional gas delivered through pipelines threatens Russia's strategic interests in the global gas market. This is illustrated by the deteriorating situation of Gazprom. The fact that LNG was ignored for the last 20 years is now seen as a significant strategic error, resulting in the loss of the company's market position. In 2008, Gazprom was a leading global company with a market capitalization of USD365bn, and its president announced that the company's capitalization would reach USD1 trillion within the next 7-8 years. Instead Gazprom has transformed into a medium-sized company with a current capitalization of USD54bn.

Gazprom's position on the Russian market has also weakened. It has lost its position as the most important Russian company and the "flagship" of the Russian economy, and fell to the $4^{\text {th }}$ place in terms of market capitalization. This decline became particularly visible in September of 2018, when Gazprom's competitor on the gas market Novatek a company that has been created from scratch and that has an incomparably lower potential - achieved a higher market capitalization. These trends are interpreted as an expression of disapproval of Gazprom's strategy and the lack of confidence among investors in the effectiveness of its infrastructural investments. Meanwhile, Novatek's strategy based on investing in LNG development is met with a positive reception.

\section{Conclusion}

From the analysis done on the Russian case, we see that it will be a waste of resources for Iran to continue dreaming about constructing gas pipelines to Europe. There are even geopolitical concerns for this as Russia does not want Iran to export independently its gas resources to Europe. For this, Russia pressures Turkey not to go on with any Iranian proposal for such gas pipeline construction. On the pragmatic side, Iran will gain more by beginning mending its ties with Europe and if possible USA, so that it can begin working on the construction of LNG facilities in Iran. The technological deficit means that Iran needs to have minimum stability in its internal politics and positive relations with the West. Considering the possibility of LNG, Iran can be a good solution to European dependency on Russia, though it will take more than a decade for Iran to boost its gas production to a level that can begin competing with Russia. On the linguistic side, this article brought important points of reflection in the manner government tries to influence the country as a whole in the pursuit of gas pipelines through special socio-linguistic elements such as independence and self-sufficiency.

\section{References}

BP Statistical Review of World Energy 2016 (June 2017).

British Petroleum, 2015. "BP Statistical Review of World Energy" (64th edition, June, 2015).

Business Monitor International (BMI) Research, Iran Power Report Q1 2018.

Carter, S. (2014). "Iran, Natural Gas and Asia's Energy Needs: A Spoiler for Sanctions?," Middle East Policy 21, no. 1 (March 11, 2014): 41-61. https://doi.org/10.1111/mepo.12056

Correljé, A., Groenleer, M., \& Veldman, J. (2013). Understanding Institutional Change: The Development of Institutions for the Regulation of Natural Gas Transportation Systems in the U.S. and the EU, EUI Working Paper RSCAS. https://doi.org/10.2139/ssrn.2225486

Eurostat, (2018). EUROSTAT Energy Data, https://ec.europa.eu/eurostat/web/energy/data

Facts Global Energy, Iran Oil and Gas Monthly January 2017, Data File (February 2018).

Gas production data: Rystad Energy UCube (January 2018 update). 
Gazprom. (2015). Gas Marketing in Europe, accessed November 9, 2015. http://www.gazprom.com/about/marketing/europe/

Habibi, N. (2014). Can Rouhani Revitalize Iran's Oil and Gas Industry? Middle East Brief, 80(2014), 1-10.

Khatinoglu, (2017). Wood Mackenzie Analysts Answer Questions on Iranian Gas Exports to the EU.

Makarov and Grigoriev. (2013). eds., Global and Russian Energy Outlook Up to 2040, 89.

Oettinger, G. (2011). The Completion of the EU Internal Energy Market 'Getting to 2014,' European Commission: SPEECH/11/614, 2011, http://europa.eu/rapid/press-release_SPEECH-11-614_en.htm

Oil \& Gas Journal, "Worldwide Refineries —Capacities as of January 1, 2018," (December 4, 2017), p. 1.

Oil \& Gas Journal, Worldwide look at reserves and production (December 2017).

Saul, J., \& Gloystein, H. (2014). EU Plans for Iran Gas Imports If Sanctions Go, Reuters. http://www.reuters.com/article/2014/09/24/us-eu-iran-gas-idUSKCNOHJ17M2

Singh, R. (2018). A Cognitive Approach to the Semantics in the Sacred Context: Semantic and Symbolic Function of Sacred Words. English Linguistics Research, 7(3). https://doi.org/10.5430/elr.v7n3p1

Singh, R. (2018). Albanian World-View: Co-Locativity as the Schematic Meaning of Albanian Verbal Prefix Bashke-. English Linguistics Research, 7(4). https://doi.org/10.5430/elr.v7n4p36

Singh, R. (2018). Areas of errors and difficulty for persian learners of spanish caused by the sound system differences between persian and spanish: a phonetic approach to inter-lingual system. KAAV International Journal of English, Literature, and Linguistics, 5, 1-8. Retrieved from: http://www.kaavpublications.org/journals/journal-5/abstract/abstract-1996.pdf

Singh, R. (2018). Auxiliary Verbs in Serbo-Croatian, French, Persian, Spanish and English: A Cognitive-Semantic Approach to the Auxiliary Verb Usage and Passive Voice. English Linguistics Research, 7(3). https://doi.org/10.5430/elr.v7n3p34

Singh, R. (2018). Christian And Sikh Communities In Iran And Role Of Language Identity: A Comparative Approach To The Social-Linguistic Aspects Of The Christianity And Sikhism In The Middle East. Sikh Research Journal, 3(1).

Singh, R. (2018). Derivational Grammar Model and Basket Verb: A Novel Approach to the Inflectional Phrase in the Generative Grammar and Cognitive Processing. English Linguistics Research, 7(2). https://doi.org/10.5430/elr.v7n2p9

Singh, R. (2018). Error Analysis of Persian Learners of Hausa Language: Cognitive Approach to Errors. Journal of Literature, Languages and Linguistics, 45, 10-15. Retrieved from: https://iiste.org/Journals/index.php/JLLL/article/view/42853/44147

Singh, R. (2018). Language change and directionality: A novel model for language change in Persian and Iranian languages from the sociolinguistic perspective. KAAV International journal of English, Literature, and linguistics, 5, 1-8. Retrieved from: http://www.kaavpublications.org/journals/journal-5/article/article-1876.pdf

Singh, R. (2018). Mirroring Effects and the Water Code: A Cognitive-Semantic Approach to Natural Morphology in the Religious-Cultural Context. Journal of Literature, Languages and Linguistics, 46, 37-41. Retrieved from: https://iiste.org/Journals/index.php/JLLL/article/download/43453/44769

Singh, R. (2018). Norwegian and Persian spatial prepositions: a novel comparative and syntactic approach to the spatial prepositions. KAAV international journal of English, literature, and linguistics, 5, 1-8. Retrieved from: http://www.kaavpublications.org/journals/journal-5/article/article-1788.pdf

Singh, R. (2018). Persian Spatial Prepositions: A Novel Logical Syntactical Approach to the Spatial Prepositions. Studii şi cercetări filologice. Seria Limbi Străine Aplicate. Retrieved from: http://scf-lsa.info/wp-content/uploads/2019/02/55-60-RAJDEEP-SINGH.pdf

Singh, R. (2018). Russian and Negative Prefixing: A Cognitive-Semantic Approach to the Negative Adjective Prefixing in Russian, Spanish, Persian, and English. English Linguistics Research, 7(4). https://doi.org/10.5430/elr.v7n4p7 
Singh, R. (2019). Iranian Civil Rights Movement and Independence Movement in Kosovo? European Union's Role in the Freedom Movements and State-Building. English Linguistics Research, 8(1). https://doi.org/10.5430/elr.v8n1p8

Singh, R. (2019). Niedźwiedzia Przysługa? Bear's Favor? Hidden Garden behind the Concrete Proverbs: Cognitive-Semantic Analysis of Proverbs in Persian, Polish and Spanish. English Linguistics Research, 8(1). https://doi.org/10.5430/elr.v8n1p20

Singh, R. (2019). Rajdeep Singh, the Peace Poet: Analysis of Figurative Language Used in 'La paz que venga con fuerza' Poem by Rajdeep Singh. Journal of Literature, Languages and Linguistics, 53. https://doi.org/10.7176/JLLL

Stevens, P. (2015). Prospects for Iran's Oil and Gas Sector (Chatham House: Middle East and North Africa Programme \& Environment, Energy and Resources Department, 2015)

U.S. Energy Information Administration "Iran,"2015, http://www.eia.gov/beta/international/analysis.cfm?iso=IRN; and Ruairi Patterson, "EU Sanctions on Iran: The European Political Context," Middle East Policy 20, no. 1 (March 26, 2013): 135-46. https://doi.org/10.1111/mepo.12010

Vakhshouri, S. (2015). Iran Faces Hurdles Hiking Oil Production When Sanctions Lifted, Oil \& Gas Journal, 6(2015), 30-32.

Vakhshouri. (2015). Iran's Oil Production Boost Scenarios in a Post-Sanctions Era.

Yafimava. (2013). The EU Third Package for Gas and the Gas Target Model: Major Contentious Issues Inside and Outside the EU. https://doi.org/10.26889/9781907555718 